leaders that they should accept such dangers as an inevitable price to pay for the country's successful "escape from predicament".1

It is perhaps surprising that two economists should have analysed economic reform in China almost exclusively by reference to the orthodox Great Tradition of Confucianism, wholly disregarding the Little Tradition, and in particular the history of Chinese commerce and finance. The considerable commercial exchanges found from early periods of the empire onwards 2 may also have produced, however much in the shadow of the Confucian "gentlemen", an ethic suited to the needs of the merchant "players" who played their trades in the many local and regional market towns of an already well-monetised traditional economy. Further investigation seems necessary before the authors' assumption can be safely accepted that the "horizontal" enclaves inside Confucian "verticality" have brought forth no precepts besides sheer violence by which human behaviour may be stably guided. There can, on the other hand, be no doubt that any "horizontal" ethic in China has always been secondary in relation to the dominant Confucian "verticality", and for this reason the foundations of a civil society in that country will need significant strengthening to permit smooth progress.

Wolfgang Kessler

\title{
K.D. Gaur
}

\section{Law of International Telecommunications in India}

Nomos Verlagsgesellschaft, Baden-Baden 1988, 219 S., DM 84,-

Diese Studie erscheint in der Reihe "Wirtschaftsrecht der internationalen Telekommunikation" und ist Bestandteil eines Forschungsprojekts über internationale Kommunikationssysteme des Max-Planck-Instituts für Ausländisches und Internationales Privatrecht in Hamburg. Wie die übrigen im Rahmen des Projekts erschienenen Länderberichte aus Amerika, Asien und Europa basiert dieser Band auf einem - mit abgedruckten - Fragenkatalog, der dem Leser Vergleiche der verschiedenen nationalen Berichte erleichtem soll.

Der Autor ist Leiter des "Department of Post-Graduate Studies and Research in Law" an der Utkal Universität in Bhubaneswar. Seine Studie ist in drei Teile gegliedert, deren erster sich mit dem indischen Fernmeldewesen befaßt und einen Uberblick über die organisatorischen, rechtlichen sowie technischen Rahmenbedingungen des indischen Telegraphen- und Telephonsystems vermittelt. Sodann folgt ein kürzerer Abschnitt, der sich mit Datenver-

1 cf. Thomas Metzger, Escape From Predicament. Neo-Confucianism and China's Evolving Political Culture, New York: Columbia University Press, 1977.

2 cf. Mark Elvin, The Pattem Of The Chinese Past, Stanford: Stanford University Press, 1973. 
arbeitung und Computertechnologie in Indien beschäftigt. Die einzelnen Abschnitte werden mit einer Darstellung der historischen Entwicklung des jeweiligen Bereichs eingeleitet, wobei deutlich wird, daß in Indien einige Techniken der Telekommunikation bereits sehr früh genutzt wurden (z.B. das Telephon seit 1881) und gesetzlichen Regelungen unterlagen (Indian Telegraph Act von 1885), während andere erst seit verhältnismäßig kurzer Zeit zur Anwendung kommen (Computersysteme, Satelliten), infolge massiver staatlicher Förderung jedoch in einer rapiden Entwicklung begriffen sind.

Neben akribisch eingearbeitetem Zahlenmaterial (es fehlt z.B. nicht die Angabe der Zahl sämtlicher im Lande vorhandener Briefkästen) finden sich auch kritsche Hinweise auf bestehende Mängel, insbesondere im Bereich des Telephondienstes, wo das Angebot aufgrund unzureichender staatlicher Investitionen sowohl qualitativ als auch quanitativ erheblich hinter der Nachfrage zurückbleibt.

Vor dem Hintergrund der Tatsache, daß $85 \%$ der indischen Bevölkerung in über 500.000 Dörfern leben und viele Menschen insbesondere infolge Analphabetentums wenig Zugang zu den gedruckten Medien haben, wird die besondere Bedeutung von Radio und Fernsehen hervorgehoben. Beide Massenmedien sind in Indien staatliche Monopole, die gezielt als Instrumente zur Erreichung sozialer und politischer Zwecke eingesetzt werden.

Uber den Begriff der "Telekommunikation" im engeren Sinne hinausgehend unterzieht Gaur im dritten Teil seiner Studie jedoch nicht nur in Rundfunkmedien, sondern auch die Bereiche "Presse" und "Kino" einer eingehenderen Betrachtung. Der Einbeziehung dieser Medien liegt seitens des Autors die Úberlegung zugrunde, daß sich die modernen Technologien der Telekommunikation in Indien trotz allen Fortschritts noch in der Anfangsphase befänden und daher der Presse für die Informationsversorgung sowie dem Kino für die Aufgabe der Unterhaltung eine grundlegende Bedeutung zukomme.

In diesem Zusammenhang wird schwerpunktmäßig das in Art. 19 der Indischen Verfassung garantierte Recht auf Meinungsfreiheit erörtert. Anhand einiger Präzedenzfälle wird die eher liberale Tendenz des Indischen Obersten Gerichtshofs zu diesem Thema veranschaulicht und den Bestrebungen der Regierungen - insbesondere unter Indira Gandhi - gegenübergestellt, die Meinungsf reiheit durch Verfassungsänderungen und eine restriktive Pressegesetzgebung einzuschränken.

Einige kürzere Abschnitte sind zusätzlich weiteren Medien und ihrer staatlichen Regulierung gewidmet, wobei insbesondere die Zensur von Büchern und dramatischen Werken angesprochen wird.

Angesichts der Vielzahl der in Gaurs Studie behandelten Bereiche und der Darstellung ihrer jeweils rechtlichen, technischen, verwaltungsorganisatorischen sowie historischen Aspekte vermag das Buch nur die jeweils grundlegenden Strukturen darzustellen, in deren Rahmen rechtliche Detailprobleme nur vereinzelt in vertiefter Weise erörtert werden. Es bietet sich jedoch ein interessanter und teilweise kritisch erläuterter Úberblick über die genannten 
Themen, zu deren anschaulicher Darstellung schließlich noch die im Anhang abgedruckten Statistiken, Ubersichtskarten sowie Gesetzesauszüge beitragen..

Christiane Röll

\author{
Leiden Journal of International Law \\ Published by the Leiden Joumal of International Law Foundation Vol. 1, No. 1, Leiden, \\ May 1988, 118pp., Dfl. 30 - 45,-
}

Another Journal of International Law? Yes, but not just another one. The Faculty of Law at Leiden University had a good start with its first volume of the Leiden Joumal of International Law (LJL). Both its structure and its concept are as simple as they are unusual in Europe: A Board of Editors comprising professors of international law as well as Judge Manf red Lachs shares editorial work and experience with an Editorial Staff of students of international law at Leiden University. As twofold as the structure is the concept. A nucleus formed by Student Contributions is surrounded by Leading Articles of teachers and practitioners of international law, by information on Current Legal Developments and, last but not least, the Book Review section.

The Journal does not only want to be a legal forum made by students, but also a source for students. The information given about the Telders Moot Court Competition and the plan to grant a bi-annual Hugo Grotius Award for the best student contribution submitted will ensure its attractiveness among students in both respects within and outside of the Netherlands.

The first article covers the question of Liability of International Organizations by Henry $G$. Schermers. Like the other two articles, by Costa R. Mahalu on Human Rights and Development and by Nico J. Schrijuer on the case of the UN Council for Namibia vs. Urenco, it deals with a currently disputed issue. The article by Mr. Schermers was not the "first attempt in legal literature" (p. 3) to examine the liability in international organizations from a theoretical point of view 1 as pointed out by the editors. Nevertheless, it is a new subject and of great practical relevance. The need to answer the questions involved became obvious in 1985 upon the insolvency of the International Tin Council. After a thorough introduction into the legal aspects of liability for damage the author gives a survey of the scope of liability in intemational law, of liability provisions in particular treaties of intemational law and ways of enforcement. He then clearly distinguishes between obligations of member states

1 cf. Gerhard Hoffmann, Der Durchgriff auf die Mitgliedstaaten internationaler Organisationen für deren Schulden, NJW 1988, 585 - 590. 